\title{
REPERTORIUM VAN TIJDSCHRIFTLITERATUUR OP HET GEBIED VAN ACCOUNTANCY EN BEDRIJFSHUISHOUDKUNDE
}

\section{A. ACCOUNTANCY.}

\author{
III. LEER VAN INRICHTING.
}

\section{The Accountant's Responsibility for Making Punched-Card Installations Succesful.}

Vannais, L e on E. - Dit artikel geeft een uiteenzetting van het ponskaarten systeem, alsmede van de omstandigheden waaronder het met succes zal kunnen worden toegepast. Schrijver stelt vast dat de machines zo ver ontwikkeld zijn, dat technisch aan iedere wens kan worden voldaan. Het is nu aan de adviseur van de topleiding om het juiste gebruik vast te stellen. Voor dit laatste wil schrijver richtlijnen geven en behandelt daartoe achtereenvolgens: the punched-chard principle; familiar functions; what happens in the printing mechanisme; the choice of machines and producers presents many alternatives; more machine functions; getting first things first.

Het artikel wordt vervolgd. A III 3

The Journal of Accountancy - October 1949

\section{The Accountant's Responsibility in Planning Succesful Punched-Card Installations.}

Vannais, Le on E. - D.i. het vervolg op boven weergegeven artikel. Achtereenvolgens komen de navolgende onderwerpen ter sprake: what to punch; how holes are punched in cards -1 . punching one card from another -2 . actuating punching from counters - 3. actuating punching from preset information in the punch itself 4 . actuating punching from marks on the card itself -5 . actuating punching simultaneously with typing -6 . actuating punching from punched tapes.

A III 3

The Journal of Accountancy, November 1949

\section{Toepassing van het slipsysteem in de administratie.}

Praus e, F. J. - Men spreekt van "slipsysteem" als er sprake is van boekingsbescheiden, welke ieder voor zich een enkele transactie betreffen en welke bescheiden zelf een deel van de registratuur vormen.

Een voordeel van een slipsysteem is, dat er gemakkelijk sorteerbare stukken ontstaan. Deze sorteerbaarheid vergroot echter de kans op zoekraken van de slips, waarom het noodzakelijk is, dat de cijfers van de slip in een register worden vastgelegd. Een ander voordeel van het slipsysteem is de besparing op schrijfwerk, waardoor ook de kans op het maken van overnamefouten vermindert.

Vereiste voor het invoeren van een slipsysteem is de noodzaak dat vele uniforme transacties plaats vinden.

Tot besluit worden enkele toepassingen van het slipsysteem besproken, n.l. copie verkoop-facturen worden gebruikt als debiteuren-administratie; de inkoopfacturen worden gebruikt als crediteuren-administratie; voorraden; gereedschappen magazijn; machines e.d.; effecten-administratie; incasso-administratie; verkoopadministratie; het ponskaartensysteem.

A III 3

Het Moderne Bedrijfsleven No. 12, November 1949

\section{LEER VAN DE CONTROLE.}

Eist de vertrouwens-theorie besnoeiing van de arbeid van de public-accountant.

Hebly, H. J. - Schrijver stelt zich zelf voor als een gematigd tegenstander van de vertrouwenstheorie welke door Prof. Limperg op het internationale accountants congres 1926 werd geïntroduceerd. Hij meent echter, dat het feit dat het maatschappelijk verkeer voortgaat met het verlenen van opdrachten waarvan $z \mathrm{ij}$, die de leer consequent willen toepassen, zeggen dat de accountants er zich niet langer mede moeten belasten, niet te rijmen is met de theorie dat de accountantsfunctie een vertrouwensfunctie is welke door het maatschappelijk verkeer is ingesteld. Een te absolute opvatting van de vertrouwensleer waarbij een collectiviteit - het maatschappelijk verkeer - geacht wordt vertrouwen te schenken aan een collectiviteit - de accountantsstand, acht schrijver irreëel. Het zijn tenslotte de individuele deelnemers uit beide groepen die tot elkander komen en het welslagen van hun samenwerking zal niet afhankelijk zijn van hun verknochtheid aan de vertrouwenstheorie, maar van de eigenschappen welke beantwoorden aan de omschrijving die Prof. Keuzekamp (art. M.A.B. Juni 1949) geeft van de onpartijdigheid.

A IV 2 Maandblad van Accountancy en Bedrijtshuishoudkunde Nr. 29, Oct. 1949. 